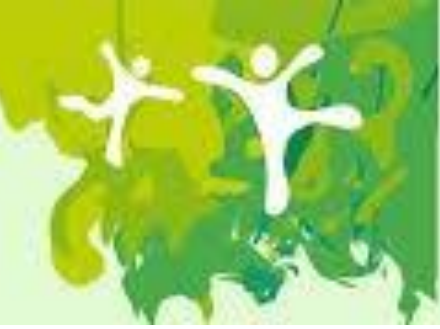

\title{
SINAIS DE SEDE IDENTIFICADOS PELO PACIENTE INFANTIL NO PÓS- OPERATÓRIO IMEDIATO
}

\section{Pôster}

Autores deste trabalho:

ANDRESSA APARECIDA RIVIERA: Universidade Estadual de Londrina-UEL

Nathalia Jung Ferreira: Universidade Estadual de Londrina-UEL

Lígia Fahl Fonseca: Universidade Estadual de Londrina-UEL

Área do Trabalho: Enfermagem pediátrica

Número de inscrição: 4826

Data da submissão:01/08/2016 às 22:49

\section{Justificativa}

Diversos fatores contribuem para o surgimento da sede na criança cirúrgica, entre eles o jejum, ansiedade, medicamento anestésicos e sangramento. O resultado é que, ao acordar da anestesia na Sala de Recuperação Anestésica (SRA), a criança apresenta sede intensa e desconfortável. No entanto, este sintoma não é valorizado, avaliado, mensurado ou registrado no pós operatório imediato. Sendo assim este sintoma não é tratado e ocasiona outros sinais de desconfortos que agitam a criança no pós-operatório imediato.

\section{Objetivo(s)}

Analisar os sinais percebidos pela criança cirúrgica durante a recuperação anestésica em relação a sede.

\section{Método(s)}

estudo quantitativo, descritivo, transversal, realizado em um hospital escola de grande porte no Paraná, na SRA. A intensidade da sede foi avaliada por escala de faces (zero a quatro) e a percepção dos sinais da sede através de questionamento com a criança, através de um roteiro semi estruturado.

\section{Resultado(s)}

A amostra foi constituída de 78 pacientes, sendo a predominância de sexo masculino (70,5\%), com idade entre 4 - 12 anos (média 7,7, mediana 8,0 e desvio padrão 2,4) e classificada como ASA I $(82,1 \%)$ e ASA II $(17,9 \%)$. As clínicas mais prevalentes foram: 
infantil (59\%), ortopedia (17.9\%) e otorrinolaringologia (11,5\%). O tempo de jejum préoperatório variou de 6 a 72 horas com média de 13,4 horas (MD = 13 e DP =7,7). Das 78 crianças avaliadas, $69(88,4 \%)$ apresentaram sede, sendo que $33(42,3 \%)$ referiram sede no pós-operatório e $28(35,9 \%)$ desde o pré-operatório. A verbalização foi espontânea com 46 (59\%) crianças. Das 69 crianças que referiram sede, 39\% (27) queixaram-se de boca seca, 7,2\% (5) garganta seca, 4,3\% (3) saliva grossa 2,4\% (3) apresentaram vontade de beber água e 47,8\% (33) apresentaram combinação de dois ou mais sinais da sede.

\section{Conclusão(ões)}

A sede no paciente cirúrgico infantil é um sintoma prevalente e intenso durante a permanência na SRA, sendo que a criança nem sempre a verbaliza espontaneamente, mas é capaz de identificar claramente os atributos desconfortáveis deste sintoma. A sede na criança cirúrgica precisa ser valorizada e avaliada adequadamente como parte inerente do processo de cuidar no pós-operatório. 